\title{
THE LEECH LIMNATIS NILOTICA AS A BIOINDICATOR FOR ORGANOCHLORINE AND POLYCHLORINATED BIPHENYL RESIDUES IN WELL WATER, AT SOME LOCALITIES OF AL-JABEL AL-AKHDAR, LIBYA RAMADANA.SALEH ${ }^{1}$,AHMEDS. BREAM ${ }^{2}$, FATMAA.SHAABAN ${ }^{3} \&$ MOHAMED A.BALAH $^{4}$ \\ 1- Faculty of science, Omer Al Mokhtar University Albiyda-Libya; 2-Faculty of science, Al Azhar University -Cairo-Egypt; 3-Faculty of Natural Resources, Omer Al Mokhtar University, Al-bayda-Libya; 4- Pesticide unit -Desert Research Center-Cairo - Egypt.
}

\begin{abstract}
Pesticides play a critical role in maintaining agricultural productivity, but intensive practice, repeated use and run off into the surface and ground water can pose a threat to the human and his domesticated animals. The study was carried out to identify the level of organochlorine pesticides and polychlorinated biphenyl residues in water wells using Limnatis nilotica leeches as bioindicators during summer and spring of the year 2013 at some localities of Al-Jabel Al-Akhdar, Libya. The chlorinated organic pesticide residues were ranged from 0.001 to $11.449 \mathrm{ng} / \mathrm{g}$ extracted from the whole homogenate body of leeches collected from five investigated wells. The obtained results showed that $100 \%$ of the analyzed samples contained detectable level of the monitored insecticides ( $H C H$, aldrin, dieldrin, endrin, o.p-DDE, p.p-DDE, o.p-DDD, p.p-DDD and o.p-DDT). It is found that $100 \%$ of the samples gave results with levels below the MRL for $\mathrm{HCH}$, aldrin, dieldrin, endrin concentration residues. Among all samples, $60 \%$ of the samples gave results with levels of total DDT concentration residues below the MRL, while $40 \%$ of the samples contained levels of insecticide residues above the MRL. On the other hand, there were occurrence of several polychlorinated biphenyl derivatives and $100 \%$ of the samples gave results above the level of the maximum contamination level for total PCB. The existence of total PCB at the highest levels were detected in Michael and El-Wasita wells at the summer season reaching 29 and $27 \mathrm{ng} / \mathrm{g}$, respectively. However, the lowest detected level of total PCB reached (1.00) $\mathrm{ng} / \mathrm{g}$ in leach tissues collected from Tiba well during summer season. The high levels of PCB derivatives detection in all leech samples is a health hazard reflected the continue uses of this materials source until this date and may be cause various diseases in Al-Jabel AlAkhdar areas. Generally, the attained results emphasized that leeches are useful tools in biomonitoring of both organochlorine pesticides and polychlorinated biphenyl residues.
\end{abstract}

Key words: Well water; organochlorine pesticide (OCP), polychlorinated biphenyl (PCB), leech, Limnatis nilotica, bioindicators.

\section{INTRODUCTION}

Water pollution is a major global problem which requires ongoing evaluation and revision of water resource policy at all levels and there is an urgent need to prevent contamination of available water resources from various type pollutants due to global water scarcity. Although most of these pollutants are present at low concentrations, many of them raise considerable toxicological concerns, particularly when present as components of complex mixtures (Schwarzenbach et al., 2006). Pesticides are one of chemicals contaminating water which is essential to sustain life and a satisfactory supply must be available to all. Pesticides have played a major role in achieving the maximum crop production but maximum usage and accumulation of pesticide residues is highly detrimental to aquatic and other ecosystem (Agrawal et al., 2015). The significance of presence of Endosulfans, Lin- dane and DDT in soil and ground water in close to human and animal should be taken into consideration (Ahmad 1998, Meijer 2001, Okeniyia et al., 2009). Monitoring of chlorinated organic pesticides represents a great task due to their long lasting effect in the environment (El-Mekkawi et al., 2009). Organochlorines pesticides (OCPs) such as dichlorodiphenyl ethane (e.g, DDT, DDD and DDE), cyclodiene (e.g. aldrin, dieldrin, heptachlor and endosulfan), and chlorocyclohexane (e.g. $\alpha, \beta, \gamma$ and $\delta \mathrm{HCH}$ ) are of great concern due to their highly persistent nature and global occurrence (Glynn et al., 1995). Contamination from heavy metals and organic chemicals used as pesticides pose special public health concerns because these contaminants can be toxic even in such small quantities as parts per billion (Scheidleder, 1999). On the other side, PCBs are mixtures of aromatic chemicals, manufactured by the chlorination of biphenyl in 
presence of a suitable catalyst. The empirical formula for PCBs is $\mathrm{C}_{12} \mathrm{H}_{10} \mathrm{nCl}_{\mathrm{n}}$ where $\mathrm{n}$ may be any value from 1 to 10 . PCBs with 5 or more chlorine atoms per molecule are referred to as higher chlorobiphenyls and are relatively more persistent in the environment than lower chlorobiphenyls which have four or fewer chlorine atoms (ElKady et al., 2007). Hence, there is a need for considerable research to predict these pollutants from the water bodies in a cost-effective manner. The most efficient parameter to assess pollution in streams receiving organic waste material has been shown to be the benthic invertebrate stream community (Hassan et al., 2014, Kazanci et al., 2014).Pesticides have been widely distributed and their traces can be detected in air, water and soil environment (Yadav et al., 2015). Surface water was found to be more contaminated than ground water with more number of organochlorines (OClPs) and organophosphates (OPPs) and more concentrated pesticides (Lari et al., 2014). Benthic organisms are more fixed in habitat than are diatoms. Both groups of organisms can adequately express the state of a stream with respect to pollution. Benthic organisms reveal both present and past environmental conditions, whereas diatoms fecal only present environmental conditions Gallup et al., (1970). In this regard, using the leeches, like Limnatis nilotica, as bioindicators is a useful tool for the biological assessment of pesticides pollution of the water of wells. Certain features of leeches make them potentially very useful in the biological assessment, especially in moderately polluted lowland watercourses (Koperski, 2005). Al Jabal Al Akhdar is relatively rich and has verities of water resources (groundwater, surface water, desalination and wastewater), however, these resources are mismanaged properly in integrated comprehensive approach (Hamad 2012a). Hence, there is a need for considerable research to monitoring these pollutants from the water bodies in a cost-effective manner. The current work aims to discover organochlorine pesticides residues of certain wells at Al Jabal Al-khadar region using leeches (Limnatis nilotica), as bioindicators. In addition to determine the effectiveness of using leech in detecting OCPs and PCBs residues in water with easy and safety tools.

\section{MATERIAL AND METHODS}

\section{1-Samples collection:}

Leech samples were hand-picked from surface water of five chosen wells (Borgho, Michael, Tiba, El Wasita and Alou) located in some regions of Al Jabal Al-khadar, Libya during the spring and summer seasons of the year 2013. Samples were identified by the laboratory specialist as Limnatis nilotica. Then, it thoroughly washed with dist. water, pooled to weigh $5 \mathrm{gm}$ and Kept into refrigerator till analysis processes.

\section{1-Chemicals and authentic chemical standards}

The used chemicals and solvents were special grade for pesticide residue analysis and purchased from Sigma-Aldrich (St. Louis, MI, USA). The purified water was obtained from a Milli-Q water system (Millipore, Bedford, MA, USA). Pesticide and PCB standards were obtained from Dr. Ehrenstorfer Laboratories, Augsburg, Germany. Pesticide and PCB stock solutions (approximately $1 \mathrm{mg} / \mathrm{l}$ ) of individual standards were prepared by dissolving in n-hexane and storing in a freezer $-18^{\circ} \mathrm{C}$ in glass bottles with PTFE-faced screw caps. Silica Gel, Grade 634, of 100-200 mesh size was used for sample extract clean up (AOAC, 1990).

\section{2-Samples and Extraction of pesticides and polychlorinated biphenyl (C12H10-nCln).}

Typically 5 gram of sample in $40 \mathrm{ml}$ glass vial, $20 \mathrm{ml}$ of extraction solvent (n- hexane) and 3 gram anhydrous sodium sulphate were added and mixed. The resulting mixture was immersed into an ultrasonic bath at $45^{\circ} \mathrm{C}$ for $60 \mathrm{~min}$. The solvent was concentration by rotary evaporator and extractions residues was removed by using $5 \mathrm{ml} \mathrm{n}$-hexane, then the sample was loaded into mixed silica column for clean up. The standard method of AOAC was applied for pesticides and PCP (Haynes et al., 2000).

\section{3-Extraction of pesticides from water samples}

Extracting chlorinated pesticides (Aldrin, Dieldrin, Endrin, $\alpha-\mathrm{HCH}$, beta $-\mathrm{HCH}$, LindaneGama $\mathrm{HCH}, o . p$-DDT, $p . p$-DDT, $o . p$-DDD, $p . p$ DDD, $o p$-DDE, $p . p$-DDE) residues from water samples according to standard method of AOAC (1990) by partitioning the water sample with 
The leech Limnatis nilotica As a Bioindicator for Organochlorine and Polychlorinated Biphenyl 13 equal volume from hexane: methylene chloride $(15: 85)$ three times, then the solvent evaporated to dryness and the extracted subject to clean up on column chromatography filled with activated florisil using diethyl ether as a elution solvent, after that the residue subject to analysis by GCMS (AOAC, 1990).

\section{4-Cleanup procedure:}

The sample preparation was carried out into glass columns which were $7.6 \mathrm{~cm}$ long with $1.3 \mathrm{~cm}$ of inner diameter. The columns were filled from bottom to top, with $1 \mathrm{~g}$ of anhydrous sodium sulphate, $2 \mathrm{~g}$ of neutral activated silica, 2 $\mathrm{g}$ of sulphuric acid modified activated silica and $2 \mathrm{~g}$ of anhydrous sodium sulphate. This multilayer silica column was washed with $20 \mathrm{ml}$ of $\mathrm{n}$ hexane prior to use. The sample was then eluted by $60 \mathrm{ml}$ of $\mathrm{n}$ - hexane collecting the eluent and evaporated. Finally, samples were reconstituted with $1 \mathrm{ml}$ of hexane and analyzed by GC/MS.

\section{5- Instrumentation and Operation Method:}

The GC/MS analysis of samples was performed using an Thermo GC/MS (Thermo Sciena tific Trace GC with Single Quadrupole MS DSQ II, USA ) equipped with an HP-5 MS capillary column (30 m+0.25 mm, $0.25 \mathrm{~nm}$ film thickness) the following temperature program was applied : $150{ }^{\circ} \mathrm{C}$ (hold $1.5 \mathrm{~min}$.) $-180^{\circ} \mathrm{C}$ (hold $1 \mathrm{~min}$.) -240 ${ }^{\circ} \mathrm{C}$ (hold $2 \mathrm{~min}$. injection temperature) $-250^{\circ} \mathrm{C}$ (hold $1 \mathrm{~min}$.) $-270{ }^{\circ} \mathrm{C}$ (hold to the end $60 \mathrm{~min}$.).

Helium was employed as carrier gas at $1 \mathrm{ml} / \mathrm{min}$. the injector, ion source, and transfer line were respectively set at 250,250 and $280^{\circ} \mathrm{C}$.one microliter of sample was injected in splitless mode. The mass spectrometer was operated in full scan mode (50-650) Daltons per second. The ionization was made by electronic impact at $70 \mathrm{ev}$. The detection limit range of the GCMS was 0. 001-0. $002 \mathrm{ppm}$ and the rune time was $60 \mathrm{~min}$. for the studied pesticides (Table 1) and PCB (Table 2) under the experimental conditions (Sibali et al., 2008).

\section{Statistical analysis}

Data analysis were analyzed using SPSS program (ANOVA) to determine if significant difference existed between means at 0.05 levels

Calibration curves were prepared from a stock solution of $1.0 \mathrm{mg} \mathrm{L}^{-1}$ OCPs dissolved in n-hexane by serial dilution to reach calibration concentrations of 5, 10, 20, 40 and $50 \mu \mathrm{g} \mathrm{L}^{-1}$. The peak areas of the corresponding analytes were plotted against the calibration concentrations and the regression coefficient was calculated for all analytes (Alawi et al., 2007). The calibration have an RSD $\leq 20 \%$ for the relative response factors and the correlation coefficient $R$ must be $>0.99$ for linear regression in order for the calibration to be compliant (Albro et al., 1981). The recovery efficiency ranged from $88 \%$ to $82 \%$ with coefficients of variation of $5 \%-8 \%$ for all organochlorine compounds. These calcu-

\begin{tabular}{|c|c|c|c|}
\hline \multicolumn{1}{|c|}{ Table (1): GC/MS analysis of organochlorine pesticides authentic samples. } \\
\hline Pesticides & Chemical group & $R_{\mathrm{t}}(\mathrm{Min})$. & Target ions $(\mathrm{m} / z)$ \\
\hline Aldrin & OCPs & 34.74 & $66(100 \%), 191$ \\
\hline Dieldrin & OCPs & 41.24 & $79(100 \%), 241$ \\
\hline Endrin & OCPs & 47.03 & $81(100 \%),, 281,243,191$ \\
\hline$\alpha-\mathrm{HCH}$ & OCPs & 14.81 & $181(100 \%), 183$ \\
\hline beta $-\mathrm{HCH}$ & OCPs & 19.23 & $181(100 \%), 219$ \\
\hline Lindane-Gama HCH & OCPs & 23.44 & $111(100 \%), 181$ \\
\hline$o . p$-DDT & OCPs & 52.33 & $235(100 \%), 237,165$ \\
\hline$p . p$-DDT & OCPs & 54.12 & $235(100 \%), 199$ \\
\hline$o . p$-DDD & OCPs & 44.23 & $235(100 \%), 237,199$ \\
\hline$p . p$-DDD & OCPs & 51.37 & $223(100 \%), 306$ \\
\hline$o$-DDE & OCPs & 36.43 & $246(100 \%), 248,316$ \\
\hline$p . p$-DDE & OCPs & 17.61 & $235(100 \%), 250$ \\
\hline
\end{tabular}


Table 2: Identification of polychlorinated biphenyls by retention time and fragments using GCMS.

\begin{tabular}{|c|c|c|c|c|}
\hline PCBs & Chemical Name & $R_{\mathrm{t}}$ (Min.) & M & Target ions $(m / z)$ \\
\hline PCB 28 & 2,4,4'-Trichlorobiphenyl (C12H7Cl3) & 27.48 & 257.5 & 186 \\
\hline PCB 52 & 2,2',5,5'-Tetrachlorobiphenyl(C12H6Cl4) & 31.24 & 291.9 & 220 \\
\hline PCB 101 & 2,2',4,5,5'-Pentachlorobiphenyl C12H5Cl5) & 38.09 & 326.4 & 254 \\
\hline PCB 118 & $2,3^{\prime}, 4,4^{\prime}, 5$ - pentachlorobiphenyls $\left(\mathrm{C}_{12} \mathrm{H}_{5} \mathrm{C}_{15}\right)$ & 49.73 & 326.4 & 290 \\
\hline PCB 153 & $2,2^{\prime}, 4,4^{\prime}, 5,5^{\prime}$-Hexachlorobiphenyl $(\mathrm{C} 12 \mathrm{H} 4 \mathrm{Cl} 6)$ & 51.7 & 360.8 & 288 \\
\hline PCB 138 & $2,2^{\prime}, 3,4,4^{\prime}, 5^{\prime}$-Hexachlorobiphenyl $\left(\mathrm{C}_{12} \mathrm{H}_{4} \mathrm{C}_{16}\right)$ & 55.18 & 360.8 & 322 \\
\hline PCB 180 & $2,2^{\prime}, 3,4,4^{\prime}, 5,5^{\prime}-$ heptachlorobiphenyls (C12H4Cl6) & 56.40 & 393 & 324 \\
\hline
\end{tabular}

lated values conducted to control the analytical reliability and assure recovery efficiency and accuracy of the results. These analyses were carried out in National Institute of Oceanographic and Fisheries, Alexandria, Egypt.

\section{RESULTS AND DISCUSSION}

The organochlorine pesticides (OCP) were banned in most country due to its health hazard and relatively non biodegradable residues. Therefore, table 3 showed their residues in $\mathrm{ng} / \mathrm{g}$ in the associated leach of water wells as a bioindicators for OCP and analyzed by GCMS during summer and spring of the study year at El Jabel Al-Akhdar region. The detected residues were range from 0.483 to $0.088 \mathrm{ng} / \mathrm{g}$ of $\alpha \mathrm{HCH}$ insecticide and 0.151- $0.010 \mathrm{ng} / \mathrm{g}(\beta \mathrm{HCH}), 0.068$ $0.008010 \mathrm{ng} / \mathrm{g}(\gamma \mathrm{HCH})$, while the total average range of $\mathrm{HCH}$ residues concentration was $0.622-0.151 \mathrm{ng} / \mathrm{g}$. The summarized data showed the detected residues of pesticides in the average range (0.049-0.007) $\mathrm{ng} / \mathrm{g}$ of Aldrin, (0.043-0.006) ng/g of Dieldrin, and 0.043-0.006 ng/g of Endrin with a total average range of this residues concentration by $(0.103-0.040) \mathrm{ng} / \mathrm{g}$. The existence of DDT insecticide and its derivatives in the total average concentration were ranged from 0.024 to 0.001 (o.p-DDE), 0.196-0.047 ( $p . p$ DDE), 0.036-0.006 (o.p-DDD), 0.221-0.021 (o.p- DDT), 11.214-0.064 (p.p-DDT) ng/g respectively with residues concentration total average ranged of (11.449 -0.218) ng/g (Table, 4). The obtained results showed that
$100 \%$ of the analyzed leach samples were contained detectable level of the monitored insecticides $(\mathrm{HCH}$, aldrin, dieldrin, endrin, $o . p$-DDE, $p . p$-DDE, $o . p$-DDD, $p . p$-DDD, $p . p$ DDT and $o p$-DDT). As a result of this study $100 \%$ of the samples gave results with levels of total $\mathrm{HCH}$, aldrin, dieldrin, endrin concentration residues below the MRL. However, DDT insecticides, $60 \%$ of the samples gave results with levels of total DDT concentration residues below the MRL, while $40 \%$ of the samples showed results contained levels of insecticide residues above the MRL. Lindane derivatives $\alpha \mathrm{HCH}, \beta \mathrm{HCH}$ and $\gamma$ $\mathrm{HCH}$ were appeared lower the maximum contamination level (WHO \&EPA) and less than DDT derivatives $o . p$-DDE, $p . p$-DDE, $o . p$-DDD, $p . p$-DDD, o.p-DDT). While the highest detected level of DDTs derivatives was $p$.p-DDT in Michael wells at the spring season in the studying year. In these samples the highest detected level of DDTs, reached $4.35 \mathrm{ng} / \mathrm{g}$, this value is considered above the acceptable levels (WHO, 1996, FAO/WHO 1986). The detectable amount of pesticides residue in water samples at the studied wells, the detected levels of DDTs derivatives were ranged from 35.0-4.0 ng/g and others chlorinated compounds ranged from 9.0 to 5.0 $\mathrm{ng} / \mathrm{g}$ in most studied water wells at El-Jabal Al-Akhdar regions. These supported our obtained results and confirmed that leach is useful tools in biomonitoring for both organochlorine pesticides residues. 
The leech Limnatis nilotica As a Bioindicator for Organochlorine and Polychlorinated Biphenyl 15

Table 3: The Concentration of organochlorine pesticides (OCPs) residues (ng/g) in leach (Limnatis

\begin{tabular}{|c|c|c|c|c|c|c|c|c|}
\hline Wells & & $\alpha-\mathrm{HCH}$ & beta $\mathrm{HCH}$ & $\begin{array}{l}\text { Lindane- } \\
\mathrm{G} \text { a m a } \\
\mathrm{HCH}\end{array}$ & $\mathrm{HCHs}$ & Aldrin & Dieldrin & Endrin \\
\hline \multirow[t]{2}{*}{ Borgho } & spring & 0.103 & 0.024 & 0.025 & 0.151 & 0.040 & 0.006 & 0.028 \\
\hline & summer & 0.118 & 0.042 & 0.019 & 0.179 & 0.049 & 0.022 & 0.025 \\
\hline \multirow[t]{2}{*}{ Michael } & spring & $0.483^{*}$ & 0.010 & 0.053 & $0.546^{*}$ & 0.021 & 0.036 & 0.024 \\
\hline & summer & 0.088 & 0.033 & 0.057 & 0.178 & 0.018 & 0.018 & 0.026 \\
\hline \multirow[t]{2}{*}{ Tiba } & spring & $0.322^{*}$ & 0.015 & 0.068 & $0.406^{*}$ & 0.017 & 0.006 & 0.018 \\
\hline & summer & 0.133 & 0.024 & 0.013 & 0.169 & 0.014 & 0.013 & 0.043 \\
\hline \multirow[t]{2}{*}{ El Wasita } & spring & 0.124 & 0.151 & 0.021 & 0.296 & 0.017 & 0.006 & 0.051 \\
\hline & summer & $0.436^{*}$ & 0.121 & 0.065 & $0.622 *$ & 0.007 & 0.038 & 0.006 \\
\hline \multirow[t]{2}{*}{ Alou } & spring & 0.194 & 0.119 & 0.039 & $0.353^{*}$ & 0.029 & 0.043 & 0.031 \\
\hline & summer & $0.226^{*}$ & 0.060 & 0.008 & 0.294 & 0.017 & 0.011 & 0.028 \\
\hline
\end{tabular}

Values differentiate at the levels of $* \mathrm{P}<0.05$ analyzed by SPSS program

Table 4: The Concentration of organochlorine pesticides (OCPs) residues (ng/g) in leach (Limnatis nilotica) associated with water wells.

\begin{tabular}{llllllll} 
Wells & & $o . p$-DDE & $p . p$-DDE & $o . p$-DDD & $p . p$-DDD & $\begin{array}{l}o \cdot p \\
\text { DDT }\end{array}$ & $p . p$-DDT \\
\hline \multirow{2}{*}{ Borgho } & spring & 0.006 & 0.114 & 0.006 & 0.008 & $0.221^{*}$ & 0.106 \\
& summer & 0.001 & 0.047 & 0.011 & 0.021 & 0.021 & 0.117 \\
\multirow{2}{*}{ Michael } & spring & 0.006 & 0.121 & 0.008 & 0.028 & 0.072 & $11.214^{*}$ \\
& summer & 0.024 & 0.076 & 0.006 & 0.017 & 0.069 & 0.064 \\
& spring & 0.003 & 0.163 & 0.013 & 0.008 & $0.142^{*}$ & $2.442^{*}$ \\
& summer & 0.004 & 0.082 & 0.019 & 0.024 & 0.110 & $4.396^{*}$ \\
\multirow{2}{*}{ Alou } & spring & 0.008 & $0.196^{*}$ & 0.017 & 0.008 & 0.033 & 3.433 \\
& summer & 0.019 & 0.082 & 0.036 & 0.008 & 0.060 & 0.071 \\
& spring & 0.010 & 0.115 & 0.015 & 0.018 & 0.042 & 0.175 \\
\hline
\end{tabular}

Values differentiate at the levels of $* \mathrm{P}<0.05$ analyzed by SPSS program

Table (5) illustrates the detection and concentration of polychlorinated biphenyl (PCB) derivatives in the collected leach (Limnatis nilotica) samples from water wells in El-Jabel Al-Akhder area. As a

result of this study $100 \%$ of the samples gave results with levels of total polychlorinated biphenyl (PCB) concentration residues above the level of the maximum contamination level (EPA 2009) which recorded by $0.5 \mathrm{ng} / \mathrm{g}$. In these respect, the highest level of polychlorinated biphenyl (PCB) was achieved in Michael and El-Wasita wells at the summer season by (29.0 and 2.7) $\mathrm{ng} / \mathrm{g}$ respectively. In the other hand, the lowest detected level of PCB reaching (1.00) ng/g in the leach collected from Tiba wells at summer season, which was considered above with the comparison EPA, 2009. The existence of these derivatives in concentration reflected the continue uses of this material in last decades. The study showed the occurrence of total polychlorinated biphenyl derivatives concentration higher than organochlorine pesticides levels. It could be concluded that the high levels of PCB derivatives in all leach samples indicated the uses of this material source until this date and contaminated the investigated wells. 
Ramadan A. Saleh et al .

Table 5: The Concentration of polychlorinated biphenyls (PCBs) (ng/g) in leach (Limnatis nilotica) associ-

\begin{tabular}{|c|c|c|c|c|c|c|c|c|c|}
\hline Wells & & PCB 28 & PCB 52 & PCB 101 & PCB 118 & PCB 153 & PCB 138 & PCB 180 & PCBs \\
\hline & spring & 0.083 & 0.226 & 0.033 & 0.100 & 0.143 & 0.108 & 0.389 & 1.083 \\
\hline \multirow[t]{2}{*}{ Borgho } & summer & 0.199 & 0.033 & 0.106 & 0.068 & 0.154 & $0.494^{*}$ & $0.717^{*}$ & 1.771 \\
\hline & spring & 0.115 & 0.122 & 0.043 & $0.221^{*}$ & 0.213 & $0.844^{*}$ & 1.338 & $2.896^{*}$ \\
\hline \multirow[t]{2}{*}{ Michael } & summer & 0.157 & 0.196 & 0.053 & 0.033 & 0.113 & $0.626^{*}$ & 0.331 & 1.508 \\
\hline & spring & 0.065 & 0.099 & 0.019 & 0.083 & 0.036 & 0.339 & 0.372 & 1.014 \\
\hline \multirow[t]{2}{*}{ Tiba } & summer & 0.042 & 0.049 & 0.021 & $0.113 *$ & 0.138 & $0.632 *$ & 0.554 & 1.547 \\
\hline & spring & 0.038 & 0.053 & 0.036 & 0.035 & $0.611 *$ & $0.464 *$ & $1.496^{*}$ & $2.732 *$ \\
\hline \multirow[t]{2}{*}{ El Wasita } & summer & $0.349^{*}$ & 0.279 & 0.036 & 0.082 & 0.165 & $0.485^{*}$ & 0.161 & 1.557 \\
\hline & spring & 0.035 & 0.133 & 0.061 & 0.072 & $0.336^{*}$ & $0.496^{*}$ & 0.371 & 1.504 \\
\hline Alou & summer & 0.083 & 0.067 & 0.046 & $0.156^{*}$ & 0.068 & $0.579 *$ & 0.444 & 1.443 \\
\hline
\end{tabular}

Values differentiate at the levels of $* \mathrm{P}<0.05$ analyzed by SPSS program

In conclusion, the obtained results provide important information on the current status of organochlorine pesticide (OCP) and polychlorinated biphenyl (PCB) were analyzed to assess the possible health risks to the inhabitant in the water wells by using leach (Limnatis nilotica) as a biomontoring agent . The occurrence of highly hydrophobic OCP and PCB in the studied water wells at El-Jabal Al-Akhdar regions were monitored by gas chromatography mass detectors. The data showed the lower contents of OCP compounds in water and leach samples could be explained by assuming the lower solubility of these toxic substances in water; it may be adsorption on the soil or sediment particles of the wells or due to the capability of leach to eliminate this compounds The OCP total residues levels not exceed the EPA Maximum Contaminant Level in water regardless of bioaccumulation and build up through the time in leach tissue as compared with the levels of residue in water samples. In the other hand, there was a recorded risk of polychlorinated biphenyl (PCB) derivatives presented in the target drinking water wells without proper treatment to eliminate these contaminants. These results supported by Al-Targi et al., (2011) who determined that the residues of organochlorine pesticides (OCPs) in 40 samples of human milk collected from eight rural and urban regions in El-Gabal AlAkhdar region -Libya, between March to December 2007. Also, Hamad (2012b) found that some of northern parts of Al Jabal Al Akhdar springs suffer from pollu- tion problems, as well as the lack of good use, and without any monitoring programs in term of water quality and quantity. According to AIRewashed (2012) water samples of 32 wells and 24 springs in the area situated between Shahat and Darna cities tested chemically and bacteriological in 2009/2010. He found an increased pollution was observed in springs and wells that are situated nearer to the town centers. High nitrate concentrations were recorded in some wells and springs. In accordance with the present study, this could be attributed to local percolation of waste water to the ground water sources in this area. Generally, it has been a strong correlation between non-maintained wells and springs and relatively high pollution, which suggested contamination from surface sources. The obtained results are evident for some risks from detecting OCP and PCB in leach tissues of the surface water collected from the different wells. It is clear that this monitoring point to the action needed for controlling this contamination as demanded could depending on Limnatis nilotica leaches as a bioindicators. Also, it is suggested that more extensive investigation covering all water wells in all El Jabal Al-Akhdar regions of Libya must be carried out to monitor the exact levels of all pesticide and polychlorinated bi phenyl residues.

\section{REFERENCE}

Ahmad, M. T., M. Saad, M. Ismail and S. S. Mabrouk (1998). Residues of some chlorinated hydrocarbon pesticides in rain water, soil and ground water, and their influence on some soil microorganisms, Journal of Environment International. 24: 665-67. 
The leech Limnatis nilotica As a Bioindicator for Organochlorine and Polychlorinated Biphenyl 17 Agarwal. A., R. Prajapati, O.P. Singh, S.K. Raza and L. K .Thakur (2015). Pesticide residue in water a challenging task in India. Environ Monit. Assess., 187:54-64.

Alawi M.A., M. Rasheed and M.G. AlMasri (2007). Organochlorine pesticides in sea water and sediment samples from the Aqaba Gulf. Fresenius Environm. Bull., 16(9b):1131-1136.

Albro P.W., J.T. Corbett and J.L. Schroeder (1981).Quantitative characterization of polychlorinated Biphenyl mixture (Aroclors 1248, 1254 and 1260) by gas chromatography using capillary columns. J. Chromatogr. A, 205: 103-111.

Al-Rawashdeh Z.(2012). The Problem of Groundwater Pollution in Aljabel Alakhdar Region. Libyan Agriculture Research Center. Journal International, 3 (S2):1369-1415.

Al-Targi, Z.H.M., Refaat, G. Abou El Ela* and El-Dressi, A.Y. (2011). Organochlorine pesticide residues in human breast milk in El-Gabal Al-Akhdar, Libya . International Conference on Life Science and Technology IPCBEE , 3 : 146-149.

AOAC, (1990). Official Methods of the Association Official of Analytical Chemist., Washington DC.

ElKady A. A., M. A. Abdel Wahhab, B. Henkelmann, M. H. Belal, M. Khairy, S. Morsi, S. M. Galal and K. Schramm (2007). Polychlorinated biphenyl, polychlorinated Dibenzopdioxin and polychlorinated dibenzofuran residues in sediments and fish of River Nile in the Cairo region. Chemosphere, 68: 1660-1668.

El-Mekkawi H., M. Diab, M. Zaki and A. Hassan (2009). Determination of Chlorinated Organic Pesticide Residues in Water, Sediments, and Fish from Private Fish Farms at Abbassa and Sahl Al-Husainia, Shakia Governorate. Australian Journal of Basic and Applied Sciences, 3(4): 4376-4383.

EPA's (2009). Regulated Contaminant Timeline EPA 816F-09-0004, May (1 pp, 86)

FAO/WHO CODEX ALIMETARIUS COMMISSION (1986). Codex maximum Limits for Pesticides Residues, 2nd Ed. P21-iv, 43-iv and 48-iv.

Gallup, J. D, J. M. Robertson and L. E. Streebin (1970). A comparison of macroscopic and microscopic indicators of pollution. Proc:. Okla. Acad. Sci. 50: 49-56.

Glynn, P.W., D. G. Rumbold and S.C. Sendaker (1995). Organochlorine Pesticide residues in marine sediment and biota from the northern Florida reef tract. Mar. Pollut. Bull., 30:397-402.

Hamad, S. M. (2012a). Status of Water Resources of Al Jabal Al Akhdar Region, North East Libya.. Libyan Agriculture Research Center Journal International 3 (5): 247-259.

Hamad, S. M. (2012b). Status of Groundwater Resource of Al Jabal Al Akhdar Region, North East Libya. Inter-

national journal of environment and water, 86: 68-78.

Hassan, M. M., H. M. Mahmoud and K. F. Abd El-Wakeill (2014). Community Structure of Zoobenthos in Some Freshwater Bodies in Taif, Saudi Arabia. International Journal of Advanced Research, 2: 114-127.

Haynes D., Müller J. and Carter S. (2000). Pesticide and herbicide residues in sediments and seagrasses from the Great Barrier Reef world heritage area and Queensland coast. Mar. Pollut. Bull., 41: 279-287.

Lari, S. Z., N. A Khan, K.N Gandhi, T. S. Meshram and N. P. Thacker (2014). Comparison of pesticide residues in surface water and ground water of agriculture intensive areas. J. of Environmental Health Science and Engineering, 12:11-19.

Kazanci, N.; P. Ekingen; M. Dügel; G. T. Türkmen (2014). Hirudinea (Annelida) species and their ecological preferences in some running waters and lakes. International Journal of Enviromental Science and Technology,12(3):1087-1096.

Koperski, P. (2010). Urban environments as habitats for (rare aquatic species: The case of leeches (Euhirudinea, Clitellata) in Warsaw freshwaters. Limnologica - Ecology and Management of Inland Waters. 40:( 3 ) 233240.

Koperski, P. (2005). Testing the suitability of leeches (Hirudinea, clitellata) for biological assessment of lowland streams. Polish Journal of Ecology, 53: 65-80.

Meijer, S. N., C. J. Halsall, T. Harner, A. J. Peters, W. A. Ockenden, A. E. Johnston, and K. C. Jones. (2001). Organochlorine pesticide residues in Archived UK soil, Journal of Environ. Sci. Technol. 35: 1989-1995.

Okeniyia, S. O., P. A. Egwikhideb, E. E. Akporhonore and I. E. Obazed (2009). Distribution of organochlorine and polychlorinated pesticide residues in water bodies of some rivers in northern Nigria, EJEAFChe., 8: 12691274.

Sibali, L. L., J. O. Okwonkwo and R. I. Mccrindle (2008). Determination of selected organochlorine pesticide (OCP) compounds from the Jukskei River catchment area in Gauteng, South Africa. Water SA, 34(5):611622.

Schwarzenbach, R.P., B. I. Escher, K. Fenner, T.B. Hofstetter, C.A. Johnson, U. Von Gunten, B. Wehrli (2006). The challenge of micropollutants in aquatic systems. Science, 313 (5790): 1072-1077.

Scheidleder, A. (1999). Groundwater quality and quantity in Europe Data and basic information Technical Report No. 22 p 112 European Environmental Agency.

Rajaei, S. M., H. Khorram, M. A. Mood, S. M. Rafie and D. L. Williams (2013). Oral infestation with leech Limnatis nilotica in two mixed-breed dogs. Journal of Small Animal Practice.55 (12): 648-651.

WHO, (1996). Guidelines for drinking-water quality, 2nd 
ed. Vol. 2 Health criteria and other supporting information, p. 940-949; and WHO, 1998. Addendum to Vol. 2. p. 281-283. Geneva.

Yadav, I.C. , N. L. Devi,, J. H. Syed, Z. Cheng, J. Li , G.
Zhang and K.C. Jone (2015). Current status of persistent organic pesticides residues in air, water, and soil, and their possible effect on neighboring countries: a comprehensive review of India. Science of the Total Environment 511:123-137.

\section{العلق الطبى ليمانتس نيلوتيكا كمؤشر حيوى لمتبقيات المبيدات الكلورينية العضوية و المركبات متعددة الكلور ثنائية فنيل فى مياه الابار بيعض مناطق الجبل الاخضر ، ليبيات \\ رمضان عطية صالح. على 1، احمد صابر بريم² ، فاطمة علي شعبان3 ومحمد عبد العزيز بلح4 فئل \\ -1 قسم علم الحيوان، كلية العلوم جامعة عمر المختار، البيضاء، ليبيا. \\ -2قسم علم الحيوان، كلية العلوم جامعة الأزهر (بنين) ، القاهرة، مصرة.

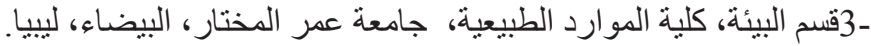 \\ -4قسم وقاية النبات، مركز بحوث الصحراء، القاهرة، مصر.}

تلعب مبيدات الافات دور حاسما فى الحفاظ على الانتاجية الزر اعية ولكن الممارسات الزر اعية المكئفة و الاستخدام

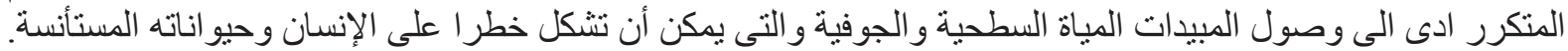

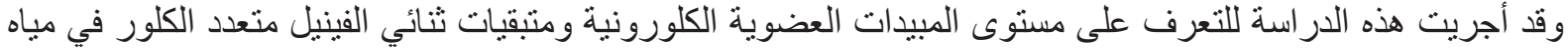

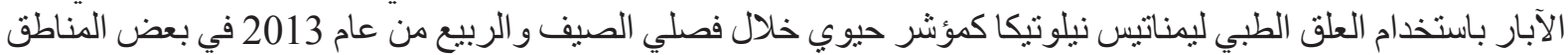

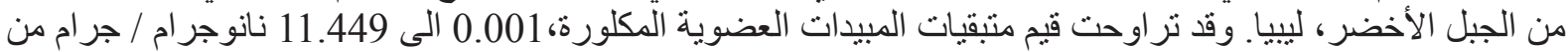

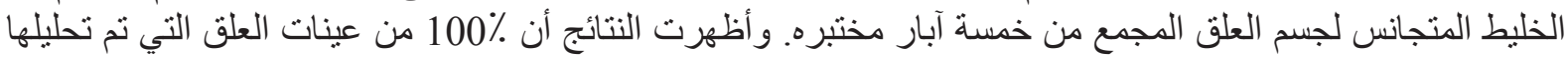

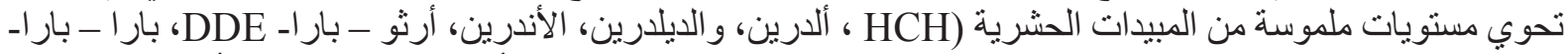

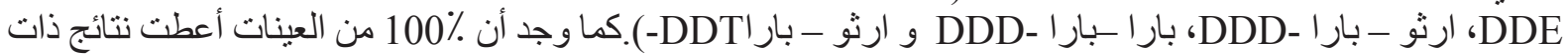

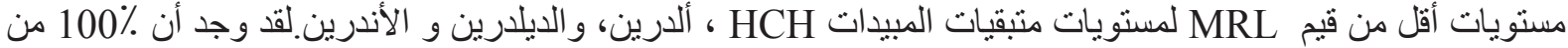

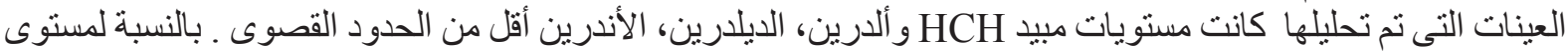

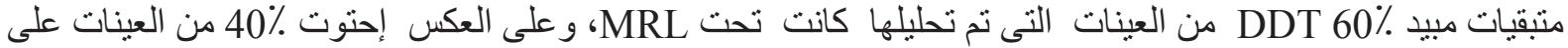
مستويات من بقايا DDT فوق الحدود القصوى.

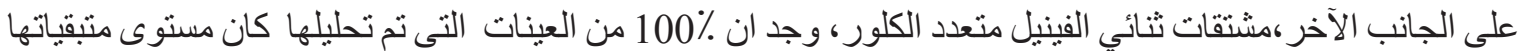

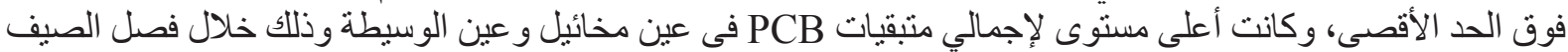

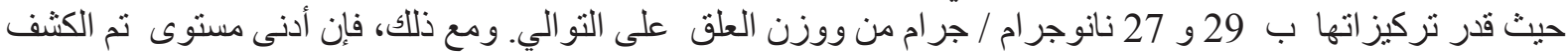

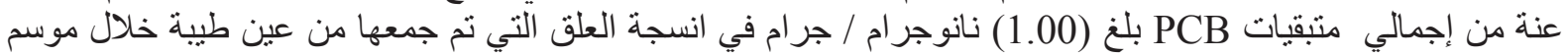

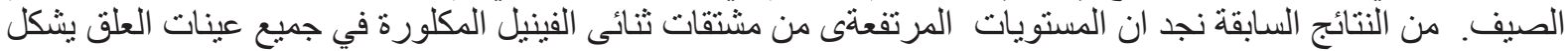

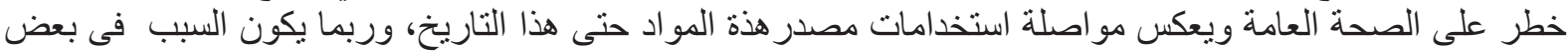

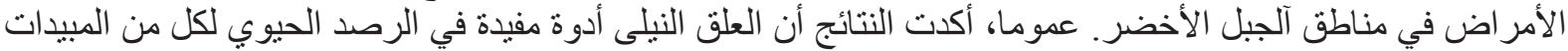
الكلورية العضوية ومخلفات ثنائي الفينيل متعدد الكلور 